\title{
Study on Prediction Method of Polymer Flooding Well Fracturing Effect Hong Pang
}

\author{
No.5 Oil Production Plant of Daqing Oilfield Company, Daqing, 163315, China \\ email: panghong1997@163.com
}

\begin{abstract}
Keyword: Percolation Mechanism, Geological Factors, Process Factor, Grey Relation, Multiple Linear Regression
\end{abstract}

\begin{abstract}
Using percolation mechanism, the geological factors and technological factors that affect the fracturing fluid were determined. Similar geological conditions and process factor, increased liquid yield of the production wells are also similar. However, the result of the oil increment is very different after fracturing. The influence factors of the oil displacement of polymer flooding are determined by grey correlation method and fuzzy mathematical analysis, which mainly includes water content of polymer flooding, water content of fracturing, single well daily production, effective thickness of fracturing layer, permeability, oil saturation and so on. On the basis of studying polymer flooding mechanism of fracturing oil increase and the variation law, using multiple linear regression method, the prediction equation of polymer flooding fracturing effect has been established. The prediction accuracy of the equation is above 95\%.
\end{abstract}

\section{Introduction}

The first polymer flooding industrial block in our factory, from March 2009 when it was put into operation to May 2016, the cumulative oil production is $60.56 \times 10^{4} \mathrm{t}$, cumulative oil increment is $53.47 \times 10^{4} \mathrm{t}$, which shows a good polymer flooding development performance. Compared with water flooding, polymer flooding is higher in oil production rate and shorter in duration. In a short time of mining, to exploit crude oil from underground as much as possible, the fracturing measures are widely adopted to increase the output of production wells. Up to now, 45 wells in the industrial area have been implemented with fracture, accounts for $35.4 \%$ of the total number of oil wells, 5.2 tons of oil of single well daily increases is obtained in the early stage of fracturing.

\section{In Polymer Flooding, Fluid Increment Prediction after Fracturing}

The average permeability of one industrial zone is $0.243 \mu \mathrm{m}^{2}$, belonging to low permeability reservoir, the fracture conductivity is much greater than the formation permeability after fracturing [1]. In the geological model of fracturing stimulate, formation fluid flows into the fractures and then wellbore [2]. Similar to the infinite homogeneous reservoir, applying the plane radial flow analysis during liquid flowing, the production yield after compression equals the definite integral of the crack length, that is:

$$
q=\int_{0}^{L}\left[k h\left(P i-P_{l}\right)\right] / B \mu r_{e} d L
$$

In the formula: $q$----yield, $\mathrm{t} / \mathrm{d}$; $k$----formation effective permeability, $\mu \mathrm{m}^{2}$; $h$----effective thickness,

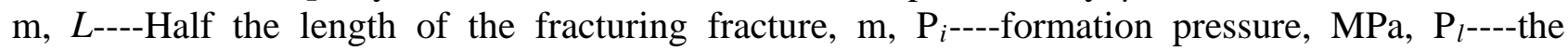
pressure of position $\mathrm{L}$ in the formation, $\mathrm{MPa}, B$----formation volume factor, $\mu$-----underground crude oil viscosity, $\mathrm{mPa} \cdot \mathrm{s}$, re----Injection production well spacing, $\mathrm{m}$.

$\mathrm{P}_{l}$ can be calculated by the by the following formula, that is:

$p_{l}=p_{f}+\int_{0}^{L}[(q-d q) B \mu L] / K_{F} h W_{f} d L$

Bring the formula (2) into the formula (1), solving the above definite integral, we get:

$q=k \times h\left(p_{i}-p_{l}\right) L n L \times K_{F} \times W_{f} /\left(B \mu r_{e}\right)$

In the formula: $p_{\mathrm{f}}$---- flow pressure of the bottom hole, MPa, $K_{F^{----}}$Fracture permeability, $\mu^{2}$, 


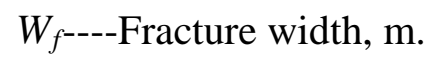

Technically assuming that the added sand content in the process of fracturing is SQ, the crack height is equal to the effective thickness, crack width $W_{f}$ is proportional to the sand mixing ratio SB. According to the regularity of our factory, generally the sand mixing ratio is 0.25 , and the value of the crack width $W f$ is approximately to $0.003 \mathrm{~m}$, here is a formula:

$W_{f} \approx 0.01 \times S B ; L \approx S Q /(0.01 h \times S B)$

Bring the formula (4) into formula (3), liquid production volume after fracturing shows below:

$$
q \approx 0.01 \times S B \times k \times h \times K_{F}(p i-p f)[L n S Q-L n h-L n S B+4.6] / B \mu r_{e}
$$

In formula (5), the related geological factors include effective thickness, permeability, formation pressure, fluid viscosity. The related process factors include sand ratio and sand content. Via this formula, the increasing amount of the fluid after fracturing can be predicted.

However, water ratio after fracturing could not be predicted via formula (5). Under the situation that the geological factors and process factors are similar among the production wells, although the amount of liquid increase after fracturing is not quite different, the oil increase after fracturing is very different.

\section{To Predict the Effect of Fracturing and Polymer Flooding on Oil Increase}

Through the analysis of the initial oil increment after the fracturing of 45 wells in the industrial zone in the different stages of polymer injection, the flowing factors were chosen as the main influencing factors of fracturing effect, which include water content in the early stage of polymer flooding, single well daily oil production in the early stage of polymer flooding, water content during fracturing, daily oil production of single well during fracturing, effective thickness of fracturing layer, permeability, porosity and oil saturation, the bottom hole flow pressure. Taking the cumulative oil increment as the dependent variable, analyzing the correlation degree between the independent variables and the dependent variables using gray correlation analysis method, the correlation degree of each influencing factor were obtained [3] (Table 1).

Table 1 correlation degree of each factor with the increasing oil quantity and the effective period

\begin{tabular}{|c|c|c|c|c|c|c|c|c|c|}
\hline $\begin{array}{c}\text { dependent } \\
\text { variable }\end{array}$ & \begin{tabular}{|c} 
Initial \\
water \\
content of \\
polymer \\
flooding
\end{tabular} & $\begin{array}{c}\text { Water } \\
\text { content } \\
\text { during } \\
\text { fracturing }\end{array}$ & \begin{tabular}{|c|} 
Single well \\
daily oil \\
production in \\
the early stage \\
of polymer \\
flooding \\
\end{tabular} & \begin{tabular}{|c} 
Daily oil \\
production of \\
single well \\
during \\
fracturing
\end{tabular} & $\begin{array}{l}\text { effective } \\
\text { thickness }\end{array}$ & permeability & porosity & oil & $\begin{array}{l}\text { Bottom } \\
\text { hole flow } \\
\text { pressure }\end{array}$ \\
\hline $\begin{array}{l}\text { Increasing } \\
\text { oil content }\end{array}$ & 0.62 & 0.83 & 0.57 & 0.77 & 0.79 & 0.701 & 0.32 & 0.824 & 0.47 \\
\hline $\begin{array}{l}\text { Term of } \\
\text { validity }\end{array}$ & 0.61 & 0.78 & 0.49 & 0.76 & 0.76 & 0.757 & 0.41 & 0.797 & 0.35 \\
\hline
\end{tabular}

The correlation degree of each factor is ranked as below.

Increasing oil content: water content during fracturing $>$ oil saturation $>$ effective thickness $>$ daily oil production of single well during fracturing>permeability>initial water content of polymer flooding $>$ single well daily oil production in the early stage of polymer flooding $>$ bottom hole flow pressure $>$ porosity.

Term of validity: oil saturation> water content of fracturing $>$ daily oil production of single well during fracturing>effective thickness>permeability>initial water content of polymer flooding $>$ single well daily oil production in the early stage of polymer flooding $>$ porosity $>$ bottom hole flow pressure.

By using the result of grey correlation analysis, the first six factors which are correlated with the increase of oil quantity are selected as the independent variables, applying multiple linear regression method together with increasing oil content, I obtain the fitting formula for increasing oil content after fracturing:

$$
\Delta Q=-6.2333+0.2599 \times X_{1}+0.1018 \times X_{2}-15.8625 \times X_{3}-8.9906 \times X_{4}+0.1199 \times X_{5}+19.5453 \times X_{6}
$$




\section{Evaluation on Practical Application Effect}

The fitting formula is verified by predicting the fracturing effect of 15 wells, the relative error of the prediction of the formula is less than $10 \%$ (Table 2 and Table 3).

Table 2 multivariate linear regression analysis of fracturing effect prediction equation

\begin{tabular}{|c|c|c|c|c|c|c|c|c|c|}
\hline $\begin{array}{l}\text { well } \\
\text { No. }\end{array}$ & $\begin{array}{c}\text { actual } \\
\text { Increased oil } \\
\text { volume } \\
\text { (t) } \Delta \mathrm{Q}\end{array}$ & $\begin{array}{c}\text { effective } \\
\text { thickness } \\
\text { (m) } X_{1}\end{array}$ & $\begin{array}{c}\text { daily oil } \\
\text { production of } \\
\text { single well } \\
\text { during } \\
\text { fracturing }(\mathrm{t}) \\
\mathrm{X}_{2} \\
\end{array}$ & $\begin{array}{l}\text { water } \\
\text { content } \\
\text { during } \\
\text { fracturing } \\
\text { (\%) } \mathrm{X}_{3}\end{array}$ & $\begin{array}{c}\text { permeability } \\
\left(\mathrm{um}^{2}\right) \mathrm{X}_{4}\end{array}$ & $\begin{array}{c}\text { oil } \\
\text { saturation } \\
(\%) \mathrm{X}_{5}\end{array}$ & $\begin{array}{c}\text { initial water } \\
\text { content of } \\
\text { polymer } \\
\text { flooding } \\
\text { (\%) } \mathrm{X}_{6}\end{array}$ & $\begin{array}{l}\text { predicted } \\
\text { oil } \\
\text { increment } \\
\text { (t) }\end{array}$ & $\begin{array}{c}\text { the } \\
\text { difference } \\
\text { (t) }\end{array}$ \\
\hline A1 & 3.0 & 7.3 & 2.0 & 0.876 & 0.201 & 43.72 & 0.897 & 2.9 & -0.1 \\
\hline A2 & 1.5 & 6.8 & 0.5 & 0.972 & 0.304 & 40.72 & 0.983 & 1.5 & 0.0 \\
\hline $\mathrm{A} 3$ & 1.1 & 4.0 & 0.8 & 0.929 & 0.453 & 50.82 & 0.966 & 1.1 & 0.0 \\
\hline A4 & 3.1 & 3.4 & 1.2 & 0.950 & 0.126 & 43.34 & 0.985 & 3.0 & -0.1 \\
\hline A5 & 4.2 & 6.7 & 4.8 & 0.852 & 0.146 & 46.85 & 0.891 & 4.2 & 0.0 \\
\hline A6 & 3.2 & 3.3 & 1.0 & 0.967 & 0.144 & 48.79 & 0.979 & 3.1 & -0.1 \\
\hline A7 & 3.4 & 7.0 & 2.1 & 0.959 & 0.280 & 49.98 & 0.988 & 3.4 & 0.0 \\
\hline A8 & 2.8 & 5.8 & 1.2 & 0.949 & 0.108 & 47.06 & 0.912 & 2.8 & 0.0 \\
\hline A9 & 2.3 & 5.0 & 0.1 & 0.983 & 0.242 & 47.44 & 0.990 & 2.3 & 0.0 \\
\hline A10 & 7.4 & 18.0 & 7.6 & 0.869 & 0.333 & 48.90 & 0.977 & 7.4 & 0.0 \\
\hline A11 & 2.1 & 18.2 & 4.0 & 0.919 & 0.158 & 0.00 & 0.981 & 2.1 & 0.0 \\
\hline A12 & 5.6 & 9.0 & 2.1 & 0.952 & 0.163 & 56.97 & 0.971 & 5.6 & 0.0 \\
\hline A13 & 6.7 & 12.0 & 7.5 & 0.886 & 0.231 & 51.21 & 0.971 & 6.6 & -0.1 \\
\hline A14 & 3.1 & 8.1 & 1.1 & 0.983 & 0.214 & 45.15 & 0.988 & 3.2 & 0.1 \\
\hline A15 & 4.1 & 7.4 & 3.4 & 0.870 & 0.199 & 49.04 & 0.911 & 4.1 & 0.0 \\
\hline A16 & 5.8 & 1.5 & 1.6 & 0.723 & 0.183 & 47.05 & 0.970 & 5.8 & 0.0 \\
\hline A17 & 3.6 & 4.9 & 3.2 & 0.857 & 0.168 & 45.72 & 0.918 & 3.7 & 0.1 \\
\hline A18 & 1.8 & 8.5 & 1.6 & 0.916 & 0.415 & 47.75 & 0.929 & 1.8 & 0.0 \\
\hline A19 & 8.7 & 8.1 & 9.1 & 0.784 & 0.100 & 49.22 & 0.988 & 8.7 & 0.0 \\
\hline A20 & 3.1 & 4.5 & 2.3 & 0.935 & 0.203 & 44.10 & 0.990 & 3.2 & 0.1 \\
\hline A21 & 5.6 & 9.3 & 6.3 & 0.881 & 0.239 & 47.89 & 0.984 & 5.7 & 0.1 \\
\hline A22 & 5.8 & 9.7 & 5.6 & 0.906 & 0.217 & 50.75 & 0.982 & 5.8 & 0.0 \\
\hline
\end{tabular}

Table 3 prediction equation of fracturing effect

\begin{tabular}{|c|c|c|c|c|c|c|c|c|c|}
\hline $\begin{array}{l}\text { well } \\
\text { No. }\end{array}$ & \begin{tabular}{|c|} 
actual \\
Increased \\
oil \\
volume \\
(t) $\Delta \mathrm{Q}$
\end{tabular} & $\begin{array}{c}\text { effective } \\
\text { thickness } \\
\text { (m) } X_{1}\end{array}$ & $\begin{array}{c}\text { daily oil } \\
\text { production } \\
\text { of single } \\
\text { well during } \\
\text { fracturing } \\
\text { (t) } \mathrm{X}_{2}\end{array}$ & $\begin{array}{c}\text { water } \\
\text { content } \\
\text { during } \\
\text { fracturing } \\
\text { (\%) } \mathrm{X}_{3}\end{array}$ & $\begin{array}{c}\text { permeability } \\
\left(\mathrm{um}^{2}\right) \mathrm{X}_{4}\end{array}$ & $\begin{array}{c}\text { oil } \\
\text { saturation } \\
(\%) X_{5}\end{array}$ & $\begin{array}{c}\text { initial } \\
\text { water } \\
\text { content } \\
\text { of } \\
\text { polymer } \\
\text { flooding } \\
\text { (\%) } \mathrm{X}_{6}\end{array}$ & $\begin{array}{l}\text { predicted oil } \\
\text { increment }(\mathrm{t})\end{array}$ & $\begin{array}{c}\text { the } \\
\text { difference } \\
\text { (t) }\end{array}$ \\
\hline B1 & 5.6 & 9.0 & 9.1 & 0.794 & 0.411 & 49.37 & 0.985 & 5.9 & 0.3 \\
\hline B2 & 3.0 & 10.2 & 2.2 & 0.950 & 0.431 & 49.98 & 0.990 & 3.0 & 0.0 \\
\hline B3 & 6.5 & 14.2 & 6.3 & 0.901 & 0.194 & 44.86 & 0.983 & 6.7 & 0.2 \\
\hline B4 & 12.8 & 8.2 & 3.6 & 0.893 & 0.157 & 44.87 & 0.979 & 5.2 & -7.6 \\
\hline B5 & 4.7 & 12.9 & 4.4 & 0.910 & 0.182 & 44.43 & 0.906 & 4.5 & -0.2 \\
\hline B6 & 3.9 & 9.3 & 1.3 & 0.937 & 0.329 & 54.24 & 0.925 & 3.1 & -0.8 \\
\hline B7 & 7.5 & 11.7 & 10.6 & 0.771 & 0.335 & 49.80 & 0.940 & 7.0 & -0.5 \\
\hline B8 & 5.6 & 16.1 & 1.0 & 0.975 & 0.172 & 44.01 & 0.988 & 5.6 & 0.0 \\
\hline B9 & 3.9 & 10.2 & 0.2 & 0.990 & 0.141 & 45.57 & 0.981 & 4.1 & 0.2 \\
\hline B10 & 2.4 & 10.7 & 1.7 & 0.965 & 0.201 & 45.38 & 0.927 & 3.2 & 0.8 \\
\hline B11 & 3.4 & 7.5 & 0.7 & 0.943 & 0.147 & 45.24 & 0.948 & 3.5 & 0.1 \\
\hline B12 & 4.6 & 9.8 & 1.5 & 0.959 & 0.152 & 45.49 & 0.986 & 4.6 & 0.0 \\
\hline B13 & 4.3 & 9.1 & 6.3 & 0.902 & 0.244 & 44.87 & 0.953 & 4.3 & 0.0 \\
\hline B14 & 3.2 & 11.5 & 3.2 & 0.927 & 0.352 & 45.10 & 0.991 & 4.0 & 0.8 \\
\hline B15 & 5.6 & 13.8 & 1.8 & 0.940 & 0.154 & 44.04 & 0.977 & 5.6 & 0.0 \\
\hline
\end{tabular}

At the same time, to study the fracturing effect of polymer flooding oil well [4], one geological 
model including 1 production well and 4 injection wells was established, with oil bearing area of $0.15 \mathrm{~km}^{2}$, geological reserves of $4.92 \times 10^{4} \mathrm{t}$, pore volume of $9.79 \times 10^{4} \mathrm{~m}^{3}$, permeability of $400-200 \mathrm{mD}$, $120 \mathrm{~m}$ well spacing, initial water content of $98 \%$, injection rate of $0.14 \mathrm{PV} / \mathrm{a}$, injection concentration of $1000 \mathrm{mg} / \mathrm{L}$, polymer dosage of $700 \mathrm{mg} / \mathrm{L}$. Numerical simulation results show that the fracturing effect of major reservoir is better the when the oil well is in the stage of water content descending or lower water content (Table 4), the fracturing effect of the thin and poor reservoir is better when the oil well is in water content recovery period. Via studying the production data of thin and poor oil layer, I found it is in the stage of low water content while the major reservoir is in the water content rising time, due to its poor reservoir conditions and effective time delaying. It can be concluded that polymer flooding formation fracturing should be optimally done when the oil well is in the stage of water content descending or lower water content. Conclusion also can be drawn from the statistical table of fracturing effect of different polymer flooding stages (Table 4), the oil increase amount and the effective period of the oil well which is in the stage of water content descending or lower water content is larger and longer than the oil well which is in water content recovery period [5].

Table 4 numerical simulation results of fracturing

\begin{tabular}{|c|c|c|c|c|c|}
\hline $\begin{array}{l}\text { scheme } \\
\text { number }\end{array}$ & content & $\begin{array}{l}\text { fracturing } \\
\text { horizon }\end{array}$ & $\begin{array}{c}\text { cumulative oil } \\
\text { increment (t) }\end{array}$ & $\begin{array}{l}\text { oil increment } \\
\text { via fracturing } \\
\quad(104 t)\end{array}$ & $\begin{array}{l}\text { recovery } \\
\text { efficiency } \\
\text { increase via } \\
\text { fracturing } \\
(\%)\end{array}$ \\
\hline $\begin{array}{l}\text { based } \\
\text { scheme }\end{array}$ & don't take fracturing measures & the whole well & 4532 & N/A & N/A \\
\hline \multirow[b]{2}{*}{ scheme $1 \#$} & \multirow{2}{*}{$\begin{array}{c}\text { fracturing the main reservoir } \\
\text { and the thin and poor reservoir } \\
\text { in the water content descent } \\
\text { period }\end{array}$} & main layer & 4727 & 0.195 & 0.96 \\
\hline & & $\begin{array}{l}\text { thin and poor } \\
\text { reservoir }\end{array}$ & 4598 & 0.067 & 0.33 \\
\hline \multirow[b]{2}{*}{ scheme $2 \#$} & \multirow{2}{*}{$\begin{array}{l}\text { fracturing the main and thin and } \\
\text { poor reservoirs in the low water } \\
\text { content stage }\end{array}$} & main layer & 4723 & 0.191 & 0.94 \\
\hline & & $\begin{array}{l}\text { thin and poor } \\
\text { reservoir }\end{array}$ & 4610 & 0.079 & 0.39 \\
\hline \multirow[b]{2}{*}{ scheme 3\# } & \multirow{2}{*}{$\begin{array}{c}\text { fracturing the main and thin and } \\
\text { poor reservoirs in the recovery } \\
\text { period of water content }\end{array}$} & main layer & 4551 & 0.018 & 0.09 \\
\hline & & $\begin{array}{l}\text { thin and poor } \\
\text { reservoir }\end{array}$ & 4652 & 0.115 & 0.57 \\
\hline scheme 4\# & $\begin{array}{l}\text { fracturing the main oil layer in } \\
\text { the water content descent } \\
\text { period, fracturing the thin and } \\
\text { poor oil layers in the recovery } \\
\text { period of water content }\end{array}$ & $\begin{array}{l}\text { main layer + thin } \\
\text { and poor } \\
\text { reservoir }\end{array}$ & 4799 & 0.267 & 1.32 \\
\hline scheme 5\# & $\begin{array}{l}\text { fracturing the main oil layer in } \\
\text { low water content stage, } \\
\text { fracturing the thin and poor oil } \\
\text { layers in the recovery period of } \\
\text { water content }\end{array}$ & $\begin{array}{l}\text { main layer }+ \\
\text { Thin and poor } \\
\text { reservoir }\end{array}$ & 4787 & 0.262 & 1.29 \\
\hline
\end{tabular}

\section{Conclusion}

The increase of fluid volume is proportional to the permeability of geological factors, fracturing thickness, the sand content and sand liquid ratio, and it is inversely proportional to the fluid viscosity. For production wells with same geological condition and process condition, there is no significant difference in fluid increment after fracturing. The oil content increment after fracturing depends on the water content and oil saturation.

\section{References}

[1] Gui Dongxu.Analysis of fracturing effect of polymer recovery wells[J]. Inner Mongolia Petrochemical Industry, 2009(24): 202-203. 
[2] Tong Shengqiang.Determination of fracturing timing of polymer flooding in bad oil layer [J].Petroleum Geology and development of Daqing, 2011,30(4): 131-134.

[3] Bi Yanchang, Su Yanchang, Li Yanxing .Application of hydraulic fracturing technology to improve the effect of polymer flooding [J]. Petroleum Geology and development of Daqing, 1999,18(3): 40-41.

[4] Zhai Yunfnag. Seepage Mechanics[M]. Petroleum Industry Press, 2009(7):13-23.

[5] Chne Taoping, Hu Jingbang[M]. Petroleum Industry Press, 2000(2):376-393. 